\title{
The Town That Food Saved: How One Community Found Vitality in Local Food
}

Ben Hewitt (2009). Ne w York, NY: Rodale. ISBN 978-1-60529-686-9. 234 pp. \$24.95, hardcover.

Review by Valerie Imbruce

Published online August 2010

Copyright (C) 2010 by New Leaf Associates, Inc.

I picked up the book The Town That Food Saved: How One Community Found Vitality in Local Food with a healthy dose of skepticism. The title sounds like a booster for how the local food movement can bring prosperity, not to mention salvation, to a hard-scrabble town. In this case the town in question is Hardwick, a rural, working-class town in northern Vermont where the unemployment rate is high and the median income low.

I recently moved to Vermont to start teaching at Bennington College, a small liberal arts college in the southern part of the state. The gossip about Hardwick was immediate. The buzz carried one message: Hardwick is a local food mecca where local agricultural development really is bringing social cohesion and economic growth to the town. Vermont in general has a very active and thoughtful local agriculture movement made up of farmers, food processors, chefs, wholesale distributors, food service directors, individual consumers, municipal and state government officials, activists, scholars... the list goes on. It would not be surprising that such a model town exists in Vermont. I had yet to see the evidence or understand what is going on in Hardwick. So along with my skepticism I started the task of reviewing this book with great curiosity.

See the publisher's site at www. rodalestore.com.
Ben Hewitt immediately laid out his own skepticism, biases, and curiosity about Hardwick in the opening of the book. He is a Vermonter, a son of homesteaders and hippies from a town very close to Hardwick. He grew up shopping at the longstanding food co-op in Hardwick. He is also a freelance journalist, an admittedly enterprising one who won a contract from Gourmet magazine to write "a great American story of redemption and pride" (p. 20) on the "agricultural uprising" (p. 19) in Hardwick. His bias about Hardwick is based on previous media coverage that portrays Hardwick and its agricultural entrepreneurs as darling. His curiosity is that of a Vermonter who loves and respects rural life and is seeking to understand a changing town that he has a personal connection to. He threads his skepticism about local agriculture through the entire book: local foods are expensive; the local foods now produced in the Hardwick area are for urbane clientele and are not

Valerie Imbruce is a faculty member and the director of environmental studies at Bennington College in Bennington, Vermont. She teaches the courses Environment and Society, The Agrarian Myth, Population, Food, and Farms, and Agroecology. Her research focus is on changing patterns of agricultural production due to urban demand, immigration, and sustainable agriculture ideology. She has conducted fieldwork in the Northeastern U.S. as well as Latin America. 
what the average Hardwick resident purchases $(\$ 20$ per pound cheese, soy products, organic seed, compost); and the sole focus on the new crop of agricultural enterprises in Hardwick ignores the mainstay of the agricultural economy in the area. Like the state of Vermont, 88 percent of Caledonia County's $\$ 31.5$ million in agricultural sales are from the dairy industry, and 97 percent of its cropland is in forage and corn for silage (USDA, 2007).

While I am heartened that Hewitt presents contradictions embedded in the local agriculture movement, I am disappointed that he does not adequately interrogate them nor explain how they play out in Hardwick. Instead he tells the Hardwick story through character portraits of its most celebrated agricultural entrepreneurs: Tom Stearns of High Mowing Organic Seeds, Mateo Kehler of Jasper Hill Farm and the Cellars at Jasper Hill, Andrew Meyer of Vermont Soy and the Center for an Agricultural Economy, Tom Gilbert of Highfields Center for Composting, Pete Johnson of Pete's Greens (Vermont's largest CSA farm). As well he includes agriculturalists who have been under the media radar to give voice to Hardwick's "old guard": Forrest Foster and Karen Shaw of Foster Farm, an old dairy that recently went organic; Steve Gorelick and Suzanna Jones who milk goats and sell blueberries to local markets; Ralph and Cindy Pearsons who run a mobile slaughter unit that services many small commercial and home meat producers; Louie Pulver and Annie Gaillard of the 25-year-old organic vegetable farm Surfing Veggie Farm.

I enjoy reading about peoples' lives and find all of these characters interesting. What emerges from the variety of viewpoints presented as most interesting to me about the Hardwick story is that there is no unified vision about the future of agriculture from this group of people, or how Hardwick is currently being saved (aside from one statistic that 100 jobs have been created). It is unfortunate that Hewitt only uses his interviews and his selection of interviewees to establish that there are two guards in Hardwick and that the old guard is distrustful, even disdainful, of the new guard. He builds this conflict around a few comments such as: "It's just guys with capital mediating between us and our needs. It's not an opportunity for us; it's being imposed on us. They talk about food security...I hate the term food security. It's a fear term. It gets people all worked up" (p. 91) and "this whole thing is ego-driven" (p. 92).

If Hewitt wanted to start a dialogue, or really get at the interesting perspectives about what is happening in Hardwick, he might have addressed each of his informants as part of the same agricultural economy. Instead he asks the old guard to comment on the new guard and asks the new guard for perspectives on themselves. Their perspectives are generally politely self-deprecating, in the vein of "I don't know what the hype is all about, I am just trying to build a socially responsible business and make a high quality product, I am not claiming to know how to change the world." I don't doubt that there are tensions between agricultural visions and entrepreneurial aspirations in Hardwick — and find this point worth exploring — but Hewitt's approach leads me to question if the dualism between the old and the new really exists or if it is inflamed for the sake of the story.

In the end there is very little evidence that Hardwick is saved by food at all, or if it even needs saving, and from what. Still, Hewitt says that there are lessons for us to take home to our communities from this story: To be creative and each do our part to improve the ways that food is grown, distributed, and ultimately eaten. What I take from this book is that there are many creative farmers and entrepreneurs in the Hardwick area who are adapting to changing social, economic, and environmental trends. But if you are really interested in the particulars of how they are adapting, what they are adapting to, and what their successes and failures have been, then you'll be disappointed in the book. If you are interested in a light-hearted, gossipy read about an inspired group of people, then this book is for you. Some of their passion just might rub off.

\section{Reference}

U.S. Department of Agriculture. (2007). Census of Agriculture. Retrieved from www.agcensus.usda.gov. 